\title{
Internationalization of Higher Education: some reflections on Russia and China
}

\author{
A internacionalização do Educação Superior: algumas reflexões \\ sobre a Rússia e China
}

\section{La internacionalización de la Educación Superior: algunas reflexiones sobre Rusia y China}

\author{
W. JOHN MORGAN* \\ ALEXANDRE ANSELMO GUILHERME**
}

\begin{abstract}
$\diamond$
Abstract

Given that there appears to be a dichotomy within the BRICS, we focus on Russia and China, discussing recent developments in their respective Higher Educational systems, and what these changes might mean in terms of internationalization. Moreover, given that the importance of Higher Education for a balanced development is something that is now widely recognised by International Organizations, such as the World Bank and UNESCO, as well as by governments, we enquire if past and current changes in Russian and Chinese Higher Educational systems have encouraged balanced development in those countries.
\end{abstract}

Keywords: Russia. China. Internationalization. Higher Education.

\section{RESUMO}

Dado que parece haver uma dicotomia entre os países que compoe os BRICS, nos concentramos na Rússia e na China, discutindo os desenvolvimentos recentes em seus respectivos sistemas de Educação Superior e o que essas mudanças podem significar em termos de internacionalização. Além disso, uma vez que a importância do Ensino Superior para um desenvolvimento equilibrado é algo agora amplamente reconhecido por Organizações Internacionais, como o Banco Mundial e a UNESCO, bem como por governos, investigamos se mudanças passadas e atuais no sistema Russo e Chinês de Educação Superior incentivaram o desenvolvimento equilibrado nesses países.

Palavras-chave: Russia. China. Internacionalização. Ensino Superior.

\section{RESUMEN}

Dado que parece existir una dicotomía dentro de los BRICS, nos centramos en Rusia y China, discutiendo los recientes desarrollos en sus respectivos sistemas de Educación Superior, y lo que estos cambios podrían significar en términos de internacionalización. Por otra parte, dado que la importancia de la Educación Superior para un desarrollo equilibrado es ahora ampliamente reconocida por Organizaciones Internacionales, como el Banco Mundial y la UNESCO, así como por los gobiernos, preguntamos si los cambios pasados y actuales en el sistemas de Educación Superior de Rusia y China han fomentado el desarrollo equilibrado en esos países.

Palabras-clave: Rusia. China. Internacionalización. Educación Superior.

* UNESCO Professor for the Political Economy of Education. Emeritus Professor, University of Nottingham, Department of Education. Emeritus Professor, Cardiff University, Department of Education.E-mail: <MorganJ74@cardiff.ac.uk>.

** PPGEdu PUCRS. PhD University of Edinburgh. E-mail: <alexandre.guilherme@pucrs.br>. 


\section{INTRODUCTION}

The term 'BRIC' was coined by Jim O'Neill in 2001 when he was chairman of Goldman Sachs Asset Management; this was published in a report entitled "Building Better Economic BRICs", which argued that Brazil, Russia, India and China would become major global economic players and that they should be incorporated into the G7 group of countries (i.e. USA, France, UK, Germany, Italy, Canada, and Japan) (GOLDMAN SACHS, 2001). The term BRICs appeared again in a report published by Goldman Sachs entitled "Dreaming with BRICs: The Path to 2050" in 2003, arguing that Brazil, Russia, India and China had embraced global capitalism and that they would transform the world's political and economic landscape. The report argued that China and India would become global suppliers of manufactured goods and services whilst Brazil and Russia of food and raw materials (cf. GOLDMAN SACHS, 2003). The first meeting of these four BRIC countries occurred in Yekaterinburg, Russia on the $16^{\text {th }}$ of June 2009 , in a summit discussing the global economic situation, the need for reform of international financial institutions, such as the World Bank and IMF, and possible ways of cooperating in the future. In the following year, 2010, South Africa showed interest in joining the group, being incorporated officially on the $24^{\text {th }}$ of December 2010. This caused the acronym to change from BRIC to BRICS, where the final S stands for South Africa.

Since then, the BRICS, working with other emerging economies, have strengthened ties, seeking to work in consonance so to consolidate their positions on the global stage and encouraging development. A classic example of this was the creation of the New Development Bank by the BRICS (http://www.ndb.int/), which aims to be an alternative to the World Bank. Also, these five countries have demanded governance reforms to the IMF and World Bank so to gain a better saying on decisions. ${ }^{1}$ Thus, it could be said that:

\footnotetext{
${ }^{1}$ In a report to the Danish Institute for International Studies, entitled "Out of the woods: Gridlock in the IMF and the World Bank puts multilateralism at risk" Vestergaard and Wade (2014: 18) note that "[m] any representatives of EMDCs [i.e. Economically More Developed Countries], including the BRICS, are becoming frustrated with western determination to cling to power in the World Bank and other important international economic governance organizations. They are plotting how to induce western states to agree to real reductions in the western 'voice'. One way is for them to move towards the exit. They have therefore been signalling that they - especially the BRICS - will 'be more careful and selective before agreeing' to activate the New Arrangements to Borrow (NAB), in the words of one participant, since it entails them handing over more money in return for very little. And the BRICS are already far advanced in the negotiations to set up a BRICS Development Bank and a BRICS Contingent [Foreign Exchange] Reserve Arrangement (for currency swaps or pooling), scheduled to be signed at the next BRICS summit in 2014".
}

what is emerging is a 'World Without the West'. This world rests on a rapid deepening of interconnectivity within the developing world - in flows of goods, money, people and ideas - that is surprisingly autonomous from Western control, resulting in the development of a new, parallel international system... The rising powers have begun to articulate an alternative institutional architecture ... [that] proposes to manage international politics through a neo-Westphalian synthesis comprised of hard-shell states... Inviolable sovereignty in the World Without the West rejects key tenets of 'modern' liberal internationalism and particularly any notion of global civil society or public opinion justifying political or military intervention in the affairs of the state (BARMA et al., 2007, p. 25-27; cf. GOLDMAN SACHS, 2003, p. 5).

However, there are some considerable differences between these five countries. China and Russia are military, and consequently diplomatic, powers, with permanent seats at the Security Council in the UN. The same could not be said of Brazil, India and South Africa. Moreover, given that China and Russia are not democratic states, their rise might "represent a return of economically successful authoritarian capitalist powers, which have been absent since the defeat of Germany and Japan in 1945" (GAT, 2007; cf. GOLDMAN SACHS, 2003, p. 6), which is again in contrast with the more democratic Brazil, India and South Africa.

In this article, given that there appears to be a dichotomy within the BRICS, we focus on Russia and China, discussing recent developments in their respective Higher Educational systems, and what these changes might mean in terms of internationalization. Moreover, given that the importance of Higher Education for a balanced development is something that is now widely recognised by International Organizations, such as the World Bank and UNESCO, as well as by governments, we enquire if past and current changes in Russian and Chinese Higher Educational systems have encouraged balanced development in those countries.

\section{RUSSIA: RECENT DEVELOPMENTS IN ITS HIGHER EDUCATION SYSTEM}

The $26^{\text {th }}$ of December 1991 is recognised as marking the birth of 'New' Russia. Much has been written about the dissolution of the USSR and the rise of the Russian Federation, and how Mikhail Gorbachev (1985-1991) and his policies of perestroika (i.e. 'restructuring') and glasnost (i.e. 'openness') played a significant role in this. Gorbachev recognised that the country could not revitalise its economy and continue spending large parts of its resources on defense. This meant that when Lithuania declared independence in 1990, he refused to send Soviet 
troops to reverse this; also, the Declaration of AlmaAta on the $21^{\text {st }}$ of December 1991 when various Soviet Republics met in the capital of Kazakhstan and decided for the dissolution of the Soviet Union (cf. COFER et al., 2015; KRAMER, 2003; O'CLERY, 2011).

This means that since the abrupt fall of the USSR, Soviet institutions had to adapt to a new context so to survive the newly established Russian conditions. The 1990s were a difficult period due to the many social, economic and political upheavals, but the 2000 s brought more stability to the country. That said, it is arguable that Russia is still a country in transition, seeking modernisation, while facing pressures from Europeanisation and Globalisation processes. The pressure to Europeanise has been a feature of Soviet and Russian Higher Education, in varying degrees and depending on the historical period, for a long time; for instance, the University of Moscow founded in 1755 was expanded and remodelled following Von Humboldt's transformation of the German Higher Education system and in spite of not being part of the European Union, Russia has adopted the Bologna Process (cf. COFER et al., 2015, p. 66-67). ${ }^{2}$ Globalisation is a relatively speaking more recent phenomenon but nevertheless it is a very pronounced and fast-paced one that is being experienced by all countries due to an increase of regional and global inter-connections at various levels (i.e. markets; information; political; culture; military; e.g. EU; World Trade Organization; NATO).

As we already mentioned, this means that the old Soviet educational system had to adapt and re-invent itself in the light of a new reality, Russia, dealing with a range of crucial issues, such as: What is the purpose of education? Who should this educational system serve? And How are we to organise and finance education? These are fundamental questions that are still being answered, and which had a significant impact on Higher Education. In this connection, it is important to note that under the leadership of Vladimir Putin, ${ }^{3}$ Russia announced a policy of innovation that forced Russian Higher Education institutions to re-invent themselves. This policy seeking modernisation is grounded on three principles: access, quality, and efficiency. It aims at establishing a modern Higher Education system, encompassing professional education, vocational training

\footnotetext{
2 For instance, Gänzle, Meister and King (2009) noted that the Bologna process has had an impact on other non-Western European countries. Since 2003 it was also embraced by Russia, and prior to that Vladimir Putin declared in 1999 that the Russian exclave of Kaliningrad, a territory between Lithuania and Poland, could serve as a place where cooperation between Russia and the EU could be piloted.

3 Vladimir Putin, was Prime Minister from 1999 to 2000, President from 2000 to 2008, and Prime Minister again from 2008 to 2012. Since 2012 he is President of the Russian Federation.
}

and adult continuing education, that would foster the development of human capital which represents a change to the more traditional role of encouraging cultural and academic developments. This represents a fundamental change because Higher Education institutions take on the role of primarily preparing individuals for contributing to the specific needs of society rather than encouraging the creation of academic knowledge and culture because such development is good in itself (cf. MORGAN and KLIUCHAREV, 2012, p. 3, 6).

It is important to note that access to Higher Education in Russia currently stands at around $78.9 \%$ of the population, which is something to be envied by both Western democracies and Russia's other BRICS partners (COFER et al., 2015, p. 73), so in a way we are speaking of a very particular system. At first the process of modernisation of Higher Education institutions in Russia counted with some support; in 2005 less than 50\% of the population supported reform. However, as changes started to be implemented, support for such changes increased reaching over $90 \%$ in 2010. Adjustments to the system included: i. the creation of data banks helping graduates find employment; ii. implementation of mobility programmes for students and academics to visit Western institutions; iii. introduction of student loans and credits; iv. creation of a national audit agency for quality assurance; v. introduction of professional bachelor degrees taught by HE institutions in conjunction with external providers. Also, through a national competition, 29 universities were chosen and given the status of National Research University, granting them a series of benefits, and a significant share of the research funding (cf. MORGAN and KLIUCHAREV, 2012, p.4).

Another important development in the Russian Higher Education system is that the private sector has increased its share of provision, and this transformation is in consonance with a more focused market economy, which in its more enhanced and contemporary version covers not only the production of material goods, financial trades and service provisions but also the creation and dissemination of knowledge (BJARNASON, CHENG and FIELDEN, 2009; cf. GEROIMENKO, KLIUCHAREV and MORGAN, 2012, p. 77). The impact is also noticed in the public sector, which has also embraced the market economy; for instance, Bjarnason, Cheng and Fielden (2009, p. 22) comment that " 40 per cent of the Russian Federation's public university students are "private", this means that Russian public universities "may enforce admissions quotas for 'public' students with no or low tuition fees but then have another quota for fee-paying students". In this connection, Cofer et al. (2015, p. 71) notes that public Higher Education institutions in Russia became more business-like through allowing them to 
access an extra source of funding by charging annual and matriculation fees to part of their students; and whilst there was a high demand for places both private and public Higher Education institutions implemented a policy of access based fundamentally on merit and capacity to pay (ZAJDA, 2007).

This kind of scenario has often been criticised by defenders of the public sector, especially with regards to the quality of education that might be offered by private providers, particularly by for-profit organizations. ${ }^{4}$ This generates a paradox because the public sector offers normally high quality education but it does so to a small section of society, and private for-profit institutions provide an education of a lesser quality but to a larger proportion of society. ${ }^{5}$ That is to say, the élites will always maintain access to high quality institutions, which are usually the state institutions. This is a perverse situation because from an equity point of view those who come from a privileged background end up getting access to top public institutions through the free public part. This is so because they attended private secondary schools, which usually have a good tracking record in placing students in top universities. (cf. also SLANTCHEVA and LEVY, 2007). This kind of perverse scenario is also experienced in other countries, such as Brazil, where students from privileged backgrounds are better prepared to pass the entry exams of top Brazilian universities because they attended private secondary schools, which better prepare them for such exams.

Hence, in Russia, "[t]he primary motive when public universities establish business plans to open private modules is income generation, sometimes to crosssubsidize the university's mainstream and sometimes to compete with a rising private, semi-elite threat"

\footnotetext{
${ }^{4}$ Moodys, a major and global credit rating agency, has developed a methodology for rating universities so that private equity investors can have better assurances to lend money to Higher Education institutions. Mexican, American and British universities have now been accessed by this methodology. Further, for-profit institutions have also gained a bigger share of the market through borrowing and opening their capitals in the stock exchange; a prime example of this is the Brazilian group, Anhanguera Educacional SA, which borrowed from International Finance Corporation (IFC) and Banco Patria to build various campuses in small cities in Brazil, which allowed them to increase their number of students from 23,000 to 46,000, as well as to float their share in the Sao Paulo Stock Exchange in 2007 (BJARNASON, CHENG and FIELDEN, 2009, p. 41; cf. also HAHN, 2007)

5 It must be noted here that there is a third kind of institutions, the so called private not-for-profit organizations, which are also called communitarian institutions in some countries, such as Brazil. These are institutions that are usually linked to religious orders or institutions and that can provide education of the highest quality, and examples of this are the various Pontifical universities in Latin America. AS McCowan (2016, p. 220) says when commenting of the case of Brazil: "There are also a number of religious universities in Brazil - most important of which are the Catholic universities (Pontifícia Universidade Católica, PUC) - that are distinct from the for-profit sector in their ethos and range of activities, and have a greater resemblance to the public universities in terms of their research and community engagement".
}

(BJARNASON, CHENG and FIELDEN, 2009, p. 22). Their motivation is not primarily a social one, which might raise questions about their real roles as catalysers of transformation in society through the creation of knowledge and forming individuals that are better equipped to deal with a wide range of problems and live in a globalised world. The problem becomes even more evident if we note that in Russia: i. those living in more rural areas and from poorer backgrounds still experience limited access; and ii. women, especially from the working classes and less urbanised areas, end up accessing low ranking institutions. This situation has an impact on class mobility as finding a job, especially a good one, is inevitably linked to attaining degrees from more qualified institutions (cf. COFER et al., 2015, p. 73).

One of the problems might be that financial aid to students from less-privileged backgrounds is still in its infancy in Russia. There has been no political or institutional engagement with this question; , in trying to help and support students in need. One of the reasons for this is that it is difficult to verify a student's income in Russia because of its decentralised tax system; that said, a 'means tested' system could be adopted. This means that Russia must seek to implement a Federal system to support minority students and students from poorer backgrounds so that a fairer system to access Higher Education, and consequently effect social mobility and transform society is in place (cf. COFER et al., 2015, p. 72; PROTAPENKO, 2002, cited in HOSSLER, 2007). Such systems have already been implemented in Western democracy and in another BRICS country, namely Brazil, where the federal government has implemented a series of measures through a system of quotas to help minorities to access Higher Education as well as through heavily subsidised financial loans as well as aid.

Clancy and Goastellec (2009, p. 139; cf. COFER et al., 2015, p. 72) provide us with the reasons for adopting such measures. They note that:

the rationale is that since access to higher education is, to varying degrees, competitive, it will always privilege those with superior economic, social and cultural resources. One response is to redefine merit as the distance between the academic levels reached by students and the diverse handicaps faced by them, whether in terms of their personal characteristics, family, community or schooling experiences. This expanded definition of equality of opportunity also applies to the nature of higher education to which access is granted. The goal here is to organise access so that the student body is not only widened in the higher education system as a whole, but also within the most prestigious institutions, those which provide students with the greatest advantage and educate the national elite. 
This rationale would mean that those individuals presenting a social, cultural and economic deficit would be considered for extra support and financial help. In the case of Russia, as we have noted, this means that those individuals from rural areas and women, would be provided for (COFER et al., 2015, p. 72). The importance of widening participation in Higher Education, and in top ranking institutions, to individuals of all minorities, gender, social classes is based on a common sense understanding that talent is something that is randomly and evenly distributed in society, which means that widening participation means that society can tap into more talent from all walks of life (CLANCY and GOASTELLEC, 2009, p. 139).

\section{CHINA: RECENT DEVELOPMENTS IN ITS Higher EDUCATION SYSTEM}

In 1978, China started to implement policies that sought to modernise the country and open it to the outside world. This was just two years after the death of Mao Zedong and occurred under the leadership of Deng Xiaoping. These economic reforms, which became known as 'market socialism', started to relax trade barriers, limited privatisation of industrial production, relaxing price controls, and liberalizing controls in coastal cities (cf. HART-LANDSBERG and BURKETT, 2010; cf. COFER and SOMERS, 2015, p. 100-101). These changes provide us with some interesting numbers; for instance: i. direct investment in China jumped from $\$ 40$ billion in 1990 to $\$ 105$ billion dollars, which demonstrates that foreign private investors had gained an appetite for China, and this has a direct impact on the amount of assets and wealth generated in the country; ii. from 1978 to 2004 the percentage of those working in agriculture decreased from $71 \%$ to $47 \%$, demonstrating a shift from rural to urban areas; iii. average annual GDP has increased an average of over 9\%; and iv. GDP per capita has increased eightfold since reforms started to be implemented (cf. LEE and MALIN, 2009; COFER and SOMERS, 2015, p.101; LI et al., 2008, p.688; MIN, 2005; ZHENG et al., 2006). All this puts some pressure on the educational system, and arguably more specifically on Higher Education. This is so because these economic changes caused an expansion of a middle class, that is always concerned with quality education at all levels for their children, and since the Chinese economy has become more manufacturing based, this increases the demand for an educated workforce that can continuously improve productivity and adapt to current trends and technologies. In connection to this, Li et al. (2008, p. 688) note that: most importantly, the classical Chinese notion that education is a consumer good has been replaced by a strong belief that education is an investment, a source of future income. What is more, individual living standards have also improved, together with expectations and aspirations. Individuals and families now want to invest in higher education as a means to secure both a higher income and status in society, and they can afford to do so. With the twin pressures of demand from both the labour market and from individuals and families, the Chinese higher education system has been compelled to expand.

This means that over the past 20 years the number of Higher Education institutions grew from 1045 in 1995 to 2491 in 2013, and consequently the number of undergraduate students from 2.9 million in 1995 to 24.6 million in 2013, and of postgraduate students from 145 thousand in 1995 to 1.8 million in 2013 (cf. NBSC, 2014; LIU and MORGAN, 2015, p. 1). The public sector is by far the largest and divided into three tiers: $i$. the first tier is formed by 39 top universities that were part of the ' 985 program' which aimed at creating Chinese world-class universities, which received extra resources and benefits; ii. the second tier encompass some 100 universities that were part of the ' 211 project' that specialise in some key areas considered to be a priority for the $21^{\text {st }}$ century; iii. the third tier encompass the other public universities as well as some private universities that offer a four-year degree (cf. WANHUA, 2016, p. 457). The creation of world-class universities and centres of expertise in key-areas does not go together with the expansion in numbers because resources are allocated and prioritise quality, rather than quantity. Thus, the high growth in the Chinese Higher Education system could only be achieved with the help of the private sector, which involved both the creation of private institutions and the development of public-private partnerships within the Higher Education system because the public sector could not meet the demand.

This means that as part of those policies seeking to liberalise and transform China's social and economic spheres, two interrelated reforms were implemented in the Higher Education system, namely marketisation and decentralisation (COFER and SOMERS, 2015, p. 110). The intention with these strategies was to "introduce market forces to liberate education, create impetus for change, and encourage competition for improvement" (CAI and YAN, 2017, p. 169).

Marketisation occurred on two fronts: i. private HE institutions and ii. allowing partnerships between private and public institutions. Until the Communist Revolution in $1949,40 \%$ of the universities in China were private; however, in 1952 all these institutions were abolished following the influence of the Soviet model of higher 
education, which was very centralised and controlled; Cai (2004, p. 158) notes that in such a system, government allocate resources, appoint leaders, assign graduate jobs, and decided enrolment numbers for all institutions. During the Cultural Revolution (1966-1976), higher education was replaced with 're-education' as academics were sent off to the countryside to work the land. Soon after 1976 private universities were re-introduced in the Chinese educational system (cf. COFER and SOMERS, 2015, p. 106; CHEN, 2011; CAI and YAN, 2017). Currently, the number of private higher education institutions in China stand at around 1470 (out of a total of 2491), and 370 of these are authorised to issue four-year bachelor degrees; further, the total number of students attending private higher education institutions is over one million, which gives China one of the biggest private education sectors in the world (WANHUA, 2016, p. 458; CAO and LEVY, 2015 , p. 14). However, Wanhua (2016, p. 458) notes that:

in China, private education is complicated in ownership, governance, and finance. Some institutions might be state-owned, but they are self-financed with student tuition and fees, or industry support. Some colleges are affiliated with public universities, and known as 'independent colleges'. These colleges were created early on by the public universities as branch campuses, a relationship which allows them to collect higher tuition and fees to subsidize the main campuses. Later, branch campuses were required to be separated from the mother institutions, so they became 'independent' and currently number 318.

Decentralisation happened through allowing regional governments to finance higher education. This has meant that since 1997, the central government allowed the implementation of a system in which costs were divided up between central and regional governments as well as individuals (cf. COFER and SOMERS, 2015, p. 110; YANG, 2011). Decentralisation was also implemented through reforming the governance of Higher Education institutions, and the extent, procedure and pace of this continues to be controlled and determined by the Chinese central government; that said, it is a fact that both Regional governments and Higher Education institutions have been granted more freedom and rights (cf. UNESCO, 2014, p. 5); We quote:

the Higher Education Law stipulates the framework for decentralization in the Chinese higher education system, stating that while 'the State Council shall provide unified guidance and administration for higher education throughout the country', the local governments at the provincial level 'shall undertake overall coordination of higher education in their own administrative regions, administer the higher education institutions that mainly train local people, and the higher education institutions that they are authorized by the State Council to administer' (Higher Education Law Article 13, Chapter 1. (UNESCO, 2014, p. 14).

This has meant that there has been a push, at least in theory, for Higher Education institutions to be more autonomous, and that consequently they would have more say in teaching, recruitment, research and administration (UNESCO, 2014, p.24). However, in a national survey with academics in over 200 universities, Wang (2000) reported that there was a certain degree of dissatisfaction with regards to decentralisation, and that more should be done about it; we quote:

autonomy was considered to be lacking in the other six areas identified in the survey. Specifically, many respondents believed that autonomy was lacking in student recruitment (70 per cent), academic programmes (66 per cent), organizational structure (65 per cent), allocation of funds (57 per cent), promotion (55 per cent), income allocation (53 per cent), and recruitment of senior administrators and departmental heads (52 per cent). (UNESCO, 2014, p.24).

As we mentioned, the expansion of Higher Education in China was achieved through a process of marketisation and decentralisation. Yet, this expansion has generated some issues that must be noted here. The first challenge concerns the fact that since 1999 the Higher Education system in China has allowed for the creation of affiliated colleges; that is, these colleges are partially owned and managed by the private sector but affiliated to a public university. They offer the status and level of educational provision of a public institution, but do so through an intake of students with lower entrance examination scores and high tuition fees. Consequently, some independent private universities start to face a problem with recruiting and investment in structure and research (cf. CAO and LEVY, 2015, p. 14).

The second issue concerns the fact that students have increasingly been asked to pay a greater share of the costs involved in their education; this means that the average tuition fee in Chinese Higher Education institutions climbed extremely fast between 1995 and 2000, from 500 to 5000 Yuan. This amount is equivalent to the average annual urban, and twice the rural income (LIU and MORGAN, 2015, p. 1; cf. also WU and ZHENG, 2008). The problem with this situation is that this has increased inequalities in the country, exacerbating the differences in access between the richer and more developed EasternCoastal regions and the poorer and less industrialised Western-Inland Chinese regions. Student loans have 
been made available through a system of subsidised government loans (i.e. the Government Subsidized Student Loans Scheme - GSSLS); however, this presents a problem for the poorer strata of the population, which is always reluctant to take loans for cultural reasons (JOHNSTONE, ARORA and EXPERTON, 1998; CF. COFER and SOMERS, 2015, p. 111). At the heart of this problem is the issue of an urban-rural divide in Chinese society.

This divide had an impact on gender issues too. The position of women in Chinese society was a very traditional one, which was probably characterised by the Chinese custom of 'foot binding', which required young girls to tightly bind their feet so to modify their shape. Moreover, the established patriarchies of Chinese society understood that women were not required to be educated. With the arrival of Western missionaries in the $19^{\text {th }}$ century in coastal regions, women, even of a poorer background, started to gain access to education and higher education in some instances. The first university to taken women in was the University of Pekin in 1920, which demonstrated a momentous change in Chinese society. After the Communist Revolution in 1949, women gained even more freedoms; however, the subsequent Cultural Revolution between 1966-1976 both men and women were persecuted for being well-educated and betraying communist values. With the economic changes of the late 1970s, the implementation of policies seeking to transform Chinese society, women from Coastal-Western, and more specifically from urban areas, started to benefit as they gained access to more income brought in by the rapid economic growth and access to higher education due to an expansion of the system in the 1990s and 2000s. However, sexism is still very much present and women in rural areas still face great challenges to further their education (cf. COFER and SOMERS, 2015, p. 109-110). This means, just as in the case of Russia, support for individuals presenting a social, cultural and economic deficit needs to be widened in China. Individuals from rural areas and women must be provided for (COFER et al., 2015, p. 72). The importance of widening participation in Higher Education to individuals of all minorities, gender, social classes is based on a common understanding that talent is something that is evenly distributed in society, and so widening participation allows countries to tap into more talent, facilitating development, and building a fairer and richer society for all (CLANCY and GOASTELLEC, 2009, p. 139).

\section{ConClusion}

In this article, we focused on Russia and China, discussing recent developments in their respective Higher
Educational systems. Russia and China have made many efforts to expand their Higher Education in terms of access, provision and quality of research. Both countries have universities in the top 100 world leading university rankings:

- Russia: Lomonosov Moscow State University, which is ranked 95 in the QS Top Universities ranking of 2018;

- China: Tsinghua University, which is ranked 25; Pekin University, ranked 38; Fudan University 40; Shanghai Jiao Tong University, 62; Zheijang University, 87, and University of Science and Technology of China, 97 in the QS Top Universities ranking of 2018.

This contrasts with the other BRICS countries, Brazil, India and South Africa, which have universities in such rankings but not in the top 100. This demonstrates a disparity in the BRICS and a suggestion that Brazil, India and South Africa need to do more in support of their Higher Education systems.

Finally, it is also clear that both Russia and China must do more to widen access to women and to rural populations, and to do so in a way that allows individuals to gain admission to top world leading universities. This would allow Russia and China to tap into a wider range of talent as well as to encourage social mobility through providing opportunities for all.

\section{REFERENCES}

BARMA, N.; RATNER, E.; WEBER, S. A World Without the West". The National Interest, v. 90, p. 23-30, July-Aug. 2007.

BJARnASON, S.; CHENG, K; M.; FIELDEN, J. A New Dynamic: private higher education. Paris: UNESCO, 2009. p. $8-13$.

CAI, Y. Confronting the global and the local - a case study of Chinese Higher Education. In: Tertiary Education and Management, v. 10, issue 2, p. 157-169, 2004.

CAI, Y.; YAN, F. Universities and Higher Education. In: MORGAN, W. John., GU, Qing; LI, Fengliang. Handbook of Education in China. Cheltenham, UK and Northampton, MA, USA: Edward Elgar, 2017. p. 169-193.

CAO, Y.; LEVY, DC. China's Private Higher Education: The Impact of Public-Sector Privatisation. In: International Higher Education, p. 14-15, 2015. Available on: <https://ejournals. bc.edu/ojs/index.php/ihe/article/download/7508/6702>. (Last access on: 2017, Sept. 29).

CHEN, X. Developmental Challenges Experienced by Three Successful Private Higher Education Institutions in the People's Republic of China: A Case Study. PhD Thesis. 2011. Available on: <http://www.proquest.com> [UMI 3477860]. (Last access on: 2017, Sept. 29)

CLANCY, P.; GOASTELLEC, G. Exploring access and equity in higher education: Performance in comparative perspective. In: Higher Education Quarterly, v. 61, issue 2, p. 136-154, 2007. 
COFER, J. E.; SOMERS, P. A China e a Educação Superior. In: MOROSINI, M. C.; Somers, P. (Ed.). O Sonho da Educação Superior nos MBRICS. Porto Alegre: EdiPUCRS, 2015. p. 99-118.

COFER, J. E.; PRITCHETT, K. O.; HEITZMAN, A. C.; SOMERS, P. A Rússia e a Educação Superior. In: MOROSINI, M. C.; Somers, P. (Ed.). O Sonho da Educação Superior nos MBRICS. Porto Alegre: EdiPUCRS, 2015. p. 59-76.

GÄNZLE, S.; MEISTER, S.; KING, C. The Bologna process and its impact on higher education at Russia's margins: the case of Kaliningrad. In: Higher Education, v. 57, issue 4, p. 533-547, 2009.

GAT, A. The Return of Authoritarian Great Powers. Foreign Affairs, July/Aug. 2007. Available on: <https:// www.foreignaffairs.com/articles/china/2007-07-01/returnauthoritarian-great-powers $>$. (Last access on: 2017, Sept. 23).

GEROIMENKO, V. A.; KLIUCHAREV, G. A.; MORGAN, W. J. Private Higher Education in Russia: capacity for innovation and investment. In: European Journal of Education, v. 47, n. 1, p. 77-91, 2012.

GOLDMAN SACHS. Building Better Global Economics BRICs. 2001, Available on: <http://pro790512df.pic10. websiteonline.cn/upload/building-better-pdf_geEM.pdf>. (Last access on: 2017, Sept. 20).

GOLDMAN SACHS. Dreaming with BRICs: The Path to 2050. 2003. Available on: <https://s3.amazonaws.com/ academia.edu.documents/31055102/3 The challenge of BRICs.pdf?AWSAccessKeyId=AKİAIWOWYYGZ $2 \bar{Y}$ 53UL3 A\&Expires $=1505922634 \&$ Signature $=Z P C 2 \mathrm{dHe}$ YCnv1cNNDZM1ONAXKm9I\%3D\&response-contentdisposition=inline $\% 3 \mathrm{~B} \% 20$ filename $\% 3 \mathrm{D} 1$._Dreaming with_BRICs_the path_to_2050.pdf>. (Last access on: 2017, Sept. 20).

HAHN, R. The private financing of higher education. International Higher Education, Boston: Boston College, n. $50,2007$.

HART-LANDSBERG, M.; BURKETT, P. China and Socialism. 2010. Available on: <https://monthlyreview. org/product/china_and_socialism/>. (Last access on: 2017, Sept. 29).

HOSSLER, D.; SHONIA, O. N.; WINKLE-WAGNER, R. A policy analysis of the status of access and equity for tertiary education in Russia. European Education, v. 39, issue 2, p. 83-102, 2007.

JOHnStOnE, D. B.; ARORA, A.; EXPERTON, W. The Financing and Management of Higher Education: A Status Report on World Bank Reforms. Washington, DC: World Bank. 1998.

KRAMER, M. The Collapse of East European Communism and the Repercussions within the Soviet Union (Part 1), Journal of Cold War Studies, v. 5, issue 4, p. 178-256. 2003.

LEE, S.; MALIN, B. Education's role in China's structural transformation. In: Finance and Economics Discussion Series, Washington, District of Columbia: Board of Governors of the Federal Reserve System, 2009. p. 41.
LI, F.; MORGAN, W. J.; DING, X. The Expansion of Higher Education, Employment and Over-Education in China. International Journal of Educational Development, v. 28, p. 687-697. 2008.

LIU, D.; MORGAN, W. J. Students' Decision-Making About Postgraduate Education at G University in China: The Main Factors and the Role of Family and of Teachers. In: Asia-Pacific Education Researcher. 2015. p. 1-14 (early view).

MCCOWAN, T. Forging Radical Alternatives in Higher Education: The Case of Brazil. In: Other Education, v. 5, issue 2, p. 196-220, 2016.

MIN, W. Economic Transition and Higher Education Reform in China. PKU GSE Newsletter 089. 2005. Available on: <http:// www.gse.pku.edu.en/jianbao/200517.htm> (in Chinese). (Last access on: 2017, Sept. 29).

MORGAN, W. J.; KLIUCHAREV, G. A. Editorial: Higher Education and the Post-Soviet Transition in Russia. In: European Journal of Education, v. 47, n. 1, p. 3-8, 2012.

NBSC. China Statistical Yearbook. 2014. Available on: $<$ http://www.stats.gov.cn/tjsj/ndsj/2014/>. (Last access on: 2017, Sept. 29).

O'CLERY, C. Moscow, December 25, 1991: the Last Day of the Soviet Union. New York: Public Affairs, 2011.

PROTAPENKO, M. Student Loans in Russia. University at Buffalo, Center for Comparative and Global Studies in Education. 2002. Available on: <http://gse.buffalo. edu/org/inthigheredfinance/files/Publications/russian/ studentLoanInRussia12-29-2006.pdf> (in Russian). (Last access on: 2017, Sept. 29).

SlantCheVA, S.; LEVY, D. C. (Ed.). Private Higher Education in Post-Communist Europe: in Search of Legitimacy, New York: Palgrave-MacMillan. 2007.

UNESCO. Governance Reforms in Higher Education. LI, M.; YANG, R. (Ed.). Paris. Available on: <http://unesdoc. unesco.org/images/0023/002318/231858e.pdf>. (Last access on: 2017, Oct. 03).

VESTERGAARD, J.; WADE, R .H. Out of the woods: Gridlock in the IMF, and the World Bank puts multilateralism at risk. Copenhagen: Danish Institute for International Studies, 2014

WANG, S. M. (Ed.). Reports on China's educational development (in Chinese). Beijing: Beijing Normal University. 2000.

WANHUA, M. Massification of Chinese Higher Education: Policies and Practices. In: COLLINS, C. S.; LEE, M. N. N.; HAWKInS, J. N.; NEUBAUER, D. E. The Palgrave Handbook of Asia-Pacific Higher Education, New York: Palgrave Macmillan. 2016. p. 455-468.

WU, B.; ZHENG, Y. Expansion of higher education in China: Challenges and implications. Briefing Series, 36. 2008. Available on: <http://www.nottingham.ac.uk/cpi/documents/ briefings/briefing-36-china-higher-education-expansion.pdf>. (Last access on: 2017, Sept. 29). 
YANG, L. World Education Finance and Higher Education Access: Econometrics Analyses of International Indicators and the Implications for China. PhD Thesis. Available on: <http:// www.proquest.com> (UMI 3459080). (Last access on: 2017, Sept. 29).

ZAJDA, J. Reforms in higher education in the Russian Federation. In: European Education, v. 39, issue 2, p. 20-36. 2007.
ZHENG, J.; BIGSTEN, A.; HU, A. Can China's Growth Be Sustained? A Productivity Perspective. In: Proceedings of the PKU CCER 449 Seminar, Available on: <http://www.ccer. pku.edu.cn/download/7214-2.pdf>. (Last access on: 2017, Sept. 29).

Recebido em 10-08-2017. Aprovado em 28-12-2017. 